\title{
Economic Instruments and the Kyoto Protocol: Can Parliament Implement Emissions Trading Without Provincial Co-operation?
}

\author{
PHILIP BARTON ${ }^{\circ}$
}

The ability of the federal government to ratify the Kyoto Protocol - the international treaty to reduce greenhouse gas emissions - is uncontested by provincial governments. However, the recent provincial opposition to this treaty could result in a constitutional challenge to Parliament's domestic implementation of the binding emission targets. This potential challenge is a result of the uncertainty in Parliament's authority to implement the necessary legislation. This article examines the federal authority 10 implement emissions trading - an economic instrument into which the federal government has invested a considerable amount of research in recent years. As possible reliance for Parliament's jurisdiction over trading, three federal powers are investigated: the peace, order and good government power, the criminal law power and the trade and commerce power. While there are difficulties with reliance on each of these powers, the peace, order and good government power is likely to provide the strongest argument for federal jurisdiction. Given the federal government's lack of clear legislative authority for trading, this article finishes by examining the alternative economic instrument of emissions taxation. concluding that Parliament's power to implement taxes is much more cerlain.
Les gouvernements provinciaux ne contestent pas l'autorité du gouvernement fédéral pour ratifier le Protocole de Kyoto, le traité international visant la réduction des émissions de gaz à effet de serre. Cependant, le Parlement pourrait se voir confronté à un défi constitutionnel concernant l'application locale des limites obligatoires dëmission de gaz, conséquence de l'opposition provinciale récente à ce traité. Ce défi en puissance résulte de l'incertitude face $\grave{a}$ l'autorité parlementaire vis-à-vis de l'implantation de la législation nécessaire. Cet article examine l'autorité fédérale dans l'implantation de l'ëchange de droits d'ëmission. un instrument économique dans lequel le gouvernement fédéral a investi un montant considérable de recherche ces dernières années. Trois pouvoirs fédéraux sont à l'étude pour envisager la juridiction $d u$ Parlement sur lëchange: les dispositions relatives à la paix. l'ordre et le bon gouvernement. le droit criminel et la compétence en matière de commerce. Si l'exercice de chacun de ces pouvoirs présente des problèmes, la paix, l'ordre et le bon gouvernement offriront probablement l'argument le plus solide pour la compétence fédérale. Élant donné l'absence de la compétence législative clairement définie du gouvernement féderal concernant le commerce, cet article termine en examinant les instruments économiques alternatifs pour la taxation des émissions et conclue que les pouvoirs de taxation du Parlement sont beaucoup plus certains.

\section{TABLE OF CONTENTS}

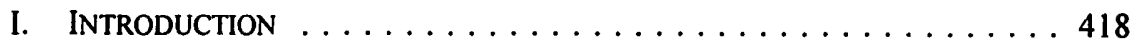

II. PeAce, ORder AND Good Government Power $\ldots \ldots \ldots \ldots 423$

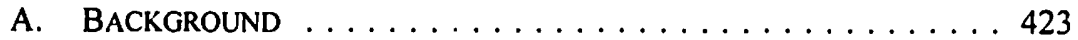

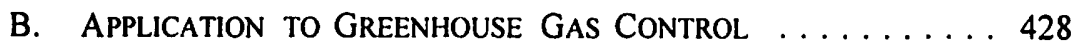

III. Criminal Law Power $\ldots \ldots \ldots \ldots \ldots \ldots \ldots \ldots \ldots \ldots \ldots \ldots$

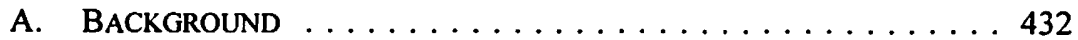

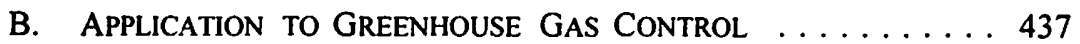

IV. TRade and Commerce Power $\ldots \ldots \ldots \ldots \ldots \ldots \ldots \ldots 440$

A. INTERPROVINCIAL AND INTERNATIONAL

TRADE AND COMMERCE $\ldots \ldots \ldots \ldots \ldots \ldots \ldots \ldots$ 


\section{B. 'General' TRADE AND COMMERCE $\ldots \ldots \ldots \ldots \ldots \ldots . \ldots 42$ \\ V. TAXATION . . . . . . . . . . . . . . . . . . . . 444

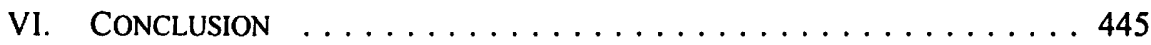

\section{INTRODUCTION}

The [federal] government wants to implement the Kyoto Protocol ... and we're talking with the provincial governments at this time to find an agreement between all the partners.

- Prime Minister Jean Chrétien, February $2002^{1}$

In December 1997 the federal government signed the Kyoto Protocol to the United Nations Framework Convention on Climate Change. ${ }^{2}$ This treaty requires industrialized nations to reduce their greenhouse gas (GHG) emissions by an average of 5.2 percent below the levels that existed in $1990{ }^{3}$ However, this treaty has yet to enter into force for it has not been ratified by Canada nor the required minimum number of nations.

Nearly five years later our federal government is still grappling with the daunting tasks of treaty ratification and domestic implementation. While the federal government has repeatedly stated its support for the Kyoto Protocol, ${ }^{4}$ the provincial support for this treaty appears to be at an all-time low. At a press conference during the recent Team Canada trade mission to Moscow, Alberta Premier Ralph Klein produced a letter which stated that all provincial premiers and territorial leaders oppose ratifying the Protocol. ${ }^{5}$ The letter stated, inter alia, "We are concerned that ratification of the Kyoto Protocol and Canada's response to climate change could impact competitiveness and, in turn, employment, economic growth and investment opportunities across Canada." While the provincial premiers of Quebec, Manitoba, Saskatchewan and Prince Edward Island later distanced themselves from the controversial letter (by expressing their support of the Protocol), ${ }^{7}$ a majority of provincial premiers remain opposed to the federal stance. Probably as a result of this opposition, and despite earlier indications that the federal government would seek ratification as early as June 2002 (in time for the G8 Summit in Kananaskis, Alberta), ${ }^{8}$ ratification has been postponed until there has been "extensive consultation with business, environmental groups and provincial governments." However, the federal Environment Minister, David Anderson, has

\footnotetext{
A. Toulin, "Business, Chrétien spar over Kyoto" National Post (28 February 2002) Al. Kyoto Protocol to the United Nations Framework Convention on Climate Change. II December 1997, (1998) 37 Int. Leg. Mat. 32 [hereinafter Kyoto Protocol].

Ibid. at Annex B.

R. Fife, "Premiers ambush Chrétien on Kyoto" National Post (16 February 2002) Al; A. Toulin, "Provinces can't stop Kyoto, Anderson says" National Post (22 February 2002) A7; A. Toulin, "Round Two set to begin in Kyoto squabble" National Post (25 February 2002) FP1; Toulin, supra note 1 .

Fife. ibid.

Ibid.

Ibid; S. McCarthy \& S. Chase, "Premiers divided over Klein's Kyoto letter" The Globe \& Mail (21 February 2002) A4; R. Fife \& R. Foot, "Premiers unity against Kyoto crumbling" National Post (2l February 2002) A2.

Fife, supra note 4; Toulin (25 February 2002), supra note 4.

I. Jack, "Ottawa sets new Kyoto approval deadline" National Post (23 March 2002) FP5.
} 
stated that his government will ratify the Kyoto Protocol even if some groups remain opposed. ${ }^{10}$ As a result, the federal course of action continues to be in a state of flux.

Canada's commitment under the Kyoto Protocol is a 6 percent reduction below 1990 levels during the commitment period of 2008 to 2012; however, national emissions have steadily increased from $607 \mathrm{Mt}^{11}$ in 1990 , to $699 \mathrm{Mt}$ in $1999 .^{12}$ Further, national emissions are projected to increase to $809 \mathrm{Mt}$ by 2010 if no climate policy initiatives are taken. ${ }^{13}$ Therefore reductions of approximately $240 \mathrm{Mt}$, a 29 percent reduction from business-as-usual practices, are necessary. The predominant source of Canada's GHG emissions is the extraction, distribution and consumption of coal, oil and natural gas - fossil fuels were estimated to account for 78 percent of national emissions in $1996 . .^{14}$

One of the main policy initiatives the federal government is investigating for reducing GHGs is domestic emissions trading, one of the two main economic instruments being considered globally for GHG control. Emissions taxation is the alternative instrument. ${ }^{15}$ This article investigates both economic instruments but focuses on trading. Currently, there are three intergovernmental working groups researching emissions trading ${ }^{16}$ and, including the National Round Table on the Environment and the Economy, numerous reports have been produced. ${ }^{17}$ Furthermore, of the four policy options presented in the new federal discussion paper on addressing climate change, three of the options rely on domestic emissions trading to reduce GHG emissions. $^{18}$

\section{$10 \quad$ Ibid}

" Mt is a simplification of the unit million tonnes (of carbon dioxide equivalent).

12 Greenhouse Gas Division - Environment Canada, Canada's Greenhouse Gas Inventory: GHG Trends Information from Environment Canada's Greenhouse Gas Division, January 2002, Factsheet $\#$ 1, online: <www.ec.gc.ca/pdb/ghg/factsheets/factl_e.cfm> (date accessed: 9 July 2002) [hereinafter Greenhouse Gas Division].

13 Government of Canada, A Discussion Paper on Canada's Contribution to Addressing Climate Change (Ottawa: Supply and Services Canada, 2002) at 15, online: <www.climatechange.gc.ca> (date accessed: 9 July 2002).

It F. Neitzert, K. Olsen \& P. Collas, Canada's Greenhouse Gas Inventory: 1997 Emissions and Removals with Trends (Ottawa: Environment Canada, 1999) at 9.

15 For a comprehensive description of both of these policy measures, refer to C. Rolfe, Turning Down the Heat: Emissions Trading and Canadian Implementation of the Kyoto Protocol (Vancouver: West Coast Environmental Law Research Foundation, 1998) [hereinafter Rolfe].

If These working groups are the Analysis and Modelling Group, the Domestic Emissions Trading Working Group, and the Emissions Allocation and Burden Sharing Working Group. Information available online at the website for the National Climate Change Process: <www.nccp.ca>. There were also two working groups in this area which completed their research in 2000: the Tradeable Permits Working Group, and the Credits for Early Action Table.

17 A small sample of the main reports includes Analysis and Modelling Group, An Assessment of the Economic and Environmental Implications for Canada of the Kyoto Protocol (Ottawa: National Climate Change Process, 2000); National Round Table for the Environment and the Economy, Canada's Options for a Domestic Greenhouse Gas Emissions Trading Program (Ottawa: Renouf Publishing, 1999); and National Round Table for the Environment and the Economy, The ABCs of Emissions Trading: An Overview (Ottawa: Supply and Services Canada, 2002) [hereinafter NRTEE]. 
Trading begins with the government setting a cap on emissions:

[E]mitters are allocated or permitted a limited amount of emissions. Emitters that reduce their emissions below their permitted levels can sell their unused permits to companies that are emitting above the level they are allowed. For some emitters it may be cheaper to buy at least some unused permits than to make investments (in new equipment, technologies, etc.) to reduce the emissions themselves. $^{19}$

The "emitters" can include businesses, governments and groups voluntarily participating. The permits can also be called "allowances," and when "emitters" reduce emissions below required levels they can generate "emission reduction credits" or simply "credits." 20 It is important to dispel the myth that trading can only apply to industry: participants in a trading regime can include municipal governments, farmers, commercial property managers, and numerous other entities. The advantage of trading is that the program encourages the most cost-effective reduction measures be undertaken, thereby "significantly [reducing] overall compliance costs."21

Taxing emissions also sends an economic incentive to reduce polluting activities. However, this signal does not differentiate between the low- and high-cost measures; taxing simply places a fixed price on the permission to pollute. Both levels of government have been consistent in their lack of enthusiasm for taxation, though ironically one of the proposals on the agenda of May's Energy and Environment Ministers conference in Charlottetown was a $10 \notin /$ litre gasoline tax. ${ }^{22}$

Given the interest in emissions trading, it is important to evaluate the legislative authority to implement a trading regime. This is of particular relevance in light of the recent vocal provincial opposition to the Kyoto Protocol. In fact, it appears likely that the constitutional authority for the federal government to control GHG emissions will be challenged by the provinces. Lorne Taylor, Alberta's Environment Minister, announced in March that provincial lawyers are investigating whether Alberta can dispute any federal measures that infringe on that province's oil industry: "I have asked our Justice Department to see if some legal case can be made about [any] kind of federal law that interferes with Alberta's resources"; ${ }^{24}$ and "we own the [oil and gas] resources, so how can Ottawa force an action on us that can really desperately damage us?"2s

\footnotetext{
NRTEE, supra note 17 at 1.

Ibid.

Ibid. at 2.

A. Toulin \& J. Taber, “Ottawa eyes 10\&/litre Gas Tax" National Post (26 April 2002) A1.

R. Remington, "Alberta Premier vows to fight "punitive' Kyoto" National Post (5 April 2002) A12;

J. Baxter, "Kyoto accord may not happen at all: Minister" National Post (19 March 2002) FP6;

S. Chase, "Kyoto report desperate act, Alberta charges" The Globe \& Mail (16 March 2002) A12;

it Chase, ibid.

$3 \quad$ Baxter. supra note 23.
} 
While not surprising, Alberta's vocal opposition to the Kyoto Protocol has only been increasing in recent months as the federal government initiates provincial Kyoto consultations. In May, Lorne Taylor warned Ottawa that the province would take its battle to the Supreme Court of Canada if need be. ${ }^{26}$ Furthermore, Taylor says Alberta has resigned as the co-chair of the National Climate Change Process, the federalprovincial working group responsible for climate-change policy, and has refused to participate in Kyoto consultations. ${ }^{27}$ He publicly stated on 22 May 2002: "We clearly will not implement the Kyoto agreement as it applies to Alberta.... We recognize [that] the federal government has every right to sign international agreements but it is very clear who owns the resource. The people of Alberta own the resources of Alberta."28 The source of Alberta's provincial authority over oil and gas resources is the same authority accorded to all provinces for jurisdiction over their respective resources s. $92 \mathrm{~A}(1)$ of the Constitution Act, $1867 .{ }^{29}$ This section states:

In each province, the legislature may exclusively make laws in relation to

(a) exploration for non-renewable natural resources in the province;

(b) development, conservation and management of non-renewable natural resources and forestry resources in the province, including laws in relations to the rate of primary production therefrom; and

(c) development, conservation and management of sites and facilities in the province for the generation and production of electrical energy.

In addition, the authority for provincial environmental initiatives has historically been held ${ }^{30}$ to be the enumerated power over "property and civil rights."

These provincial powers will likely form the basis of an important future federalprovincial debate. While it cannot be disputed that Parliament has the international legal status to ratify the Kyoto Protocol, the legislative authority to force the necessary emission reductions at home is not as clear. The Constitution only provides the federal government with the power to implement British Empire treaties. ${ }^{32}$ In the seminal Labour Conventions case ${ }^{33}$ the Judicial Committee of the Privy Council held that the federal government did not have the authority to domestically implement international treaties that interfered in areas of provincial jurisdiction; the existence of a treaty does not provide the constitutional basis for legislation. ${ }^{34}$ In fact, the Prime Minister recently confirmed, at least in his view, the lack of clear constitutional authority for

S. Haggett, "Alberta on the brink of energy showdown" Calgary Herald (23 May 2002) Al.

S. Chase, "Alberta splits from Ottawa on Kyoto deal" The Globe \& Mail (22 May 2002) A8; A. Toulin, “Alberta quits Kyoto negotiation" National Post (22 May 2002) Al.

Haggett. supra note 26.

Constitution Act, 1867 (U.K.), 30 \& 31 Vict., c. 3, reprinted in R.S.C. 1985, App. II. No. 5 [hereinafter Constitution].

R. v. Lake Ontario Cement (1973), II C.C.C. (2d) 1 (Ont. H.C.).

Constitution, supra note 29 at s. 92(13).

Ibid., s. 132.

Canada (A.G.) v. Ontario (A.G.) (Re: Labour Conventions), [1937] I D.L.R. 673 (P.C.) [hereinafter Labour Conventions case].

The Supreme Court of Canada indicated the potential for reconsideration of this issue in MacDonald v. Vapour Canada, [1977] 2 S.C.R. 134. 
enacting GHG legislation: "we need the collaboration of the provinces. We don'thave all the jurisdiction to do it."

Novel disputes about the constitutionality of proposed or enacted legislation usually fall to the Supreme Court of Canada to decide. The Court first determines the dominant purpose or "pith and substance" of the legislation. In the words of the unanimous Court: "What is its true meaning or essential character, its core?"36 The pith and substance analysis also verifies that the actual effect of the law doesn't significantly diverge from its declared objective (legislation which has an effect different from its stated objective is commonly referred to as "colourable"). ${ }^{37}$ With the pith and substance determined, the court then examines whether this purpose is essentially that of any of the enumerated powers from either ss. 91 or 92 of the Constitution. ${ }^{38}$ If the provision doesn't "find a home" ${ }^{\text {"39 }}$ within those federal or provincial powers, the court may examine the residual federal peace, order and good government power.

This article explores the legislative authority for GHG economic instruments and utilizes the published research of five lawyers which examined the federal authority to implement the Kyoto Protocol. ${ }^{40}$ Two of these lawyers - Rolfe and Castrilli provided extensive analysis. ${ }^{41}$ The four key methods identified, by which Parliament could exercise authority for GHG economic instruments, include: the peace, order and good government power (POGG power); ${ }^{42}$ the criminal law power; ${ }^{43}$ the trade and commerce power, ${ }^{44}$ and taxation. ${ }^{45}$ The GHG economic instruments analyzed trading and taxation - are both equally applicable to all the human-induced GHG emissions. Furthermore, they are not limited to energy-related emissions so can be distinguished from "energy policy."

By assuming that the federal government will ratify the Kyoto Protocol and then initiate emissions trading without the benefit of provincial cooperation, this article investigates the three mentioned federal powers which Parliament could rely upon for jurisdiction. In fact, at least in the case of Alberta, it is quite likely that there will be

S. Chase, "Provinces have Kyoto role: PM says" The Globe \& Mail (24 April 2002) A4. Reference re: Firearms Act (Can.), [2000] I S.C.R. 783 at 796 [hereinafter Firearms Reference]. lbid.

D. Gibson, "Measuring 'National Dimensions"' (1976) 7 Man. L.J. 15 at 17; R. v. Hydro-Québec, [1997] 3 S.C.R. 213 at paras. 112-13.

Gibson, ibid.

Rolfe, supra note 15 at 347-87; J.F. Castrilli, "Legal Authority for Emissions Trading in Canada," The Legislative Authority to Implement a Domestic Emissions Trading System (Ottawa: National Round Table on the Environment and the Economy, 1999) App. 1 [hereinafter Castrilli]; P.W. Hogg, "Kyoto \& Canada: A Legal Perspective" (1998) 1:3 Alberta Views 7-8; A. Bachelder, "Using Credit Trading to Reduce Greenhouse Gas Emissions" (2000) 9 J. Enviro. L. \& Practice 281 [hereinafter Bachelder]; J.E. Tyrell, "Kyoto: Law and Disorder?" C3 Views: Climate Change Central Newsletter Issue, 2 February 2002 at 9, online: <www.climatechangecentral.com/info centre/C3Views200202final.pdf $>$ (date accessed: 9 July 2002).

Rolfe, ibid.; Castrilli, ibid.

Constitution, supra note 29, s. 91 [hereinafter POGG power].

Ibid. at s. 91(27).

Jbid. at s. 91(2).

Ibid. at s. 91(3). 
a constitutional challenge to this proposed jurisdiction. Even though the federal government is only interested in emissions trading, if the constitutional basis for trading is weak, Parliament may elect to pursue the alternative economic instrument available - emissions taxation. As a result, this article consists of four parts - each part being one of the four federal powers analyzed: the peace, order and good government power; the criminal law power; the trade and commerce power; and taxation. While a pith-andsubstance analysis would attempt to match a legislation's dominant purpose with the enumerated powers of the Constitution, and only examine the residuary POGG power if this match is unsuccessful, I will reverse the approach and begin with POGG. This is a result of POGG being the strongest argument for federal authority and the two enumerated heads for trading authority (criminal and trade and commerce) being weaker arguments.

\section{Peace, Order and Good Government Power}

This section reviews the federal peace, order and good government power and then explores whether this power could serve as legislative authority for a federally administered emissions trading regime.

\section{A. BACKGROUND}

Section 91 of the Constitution confers on Parliament the following power:

to make laws for the Peace, Order and good Government of Canada. in relation to all Matters not coming within the Classes of Subjects by this Act assigned exclusively to the Legislatures of the Provinces. $^{46}$

This "peace, order and good government" power (POGG power) is interpreted as residuary to provincial powers because it is limited to "the subjects not assigned exclusively to the Legislatures of the provinces." 47 Being residuary, any matter which is not under provincial authority comes under federal jurisdiction. Parliament may only rely on this power if the subject matter is not within the provincial heads of power. ${ }^{48}$

Three branches of the POGG power have been identified and utilized over the years. These are the "gap" branch, the "national concern" branch and the "emergency" branch. ${ }^{49}$ Only the "national concern" branch is of importance from the perspective of this article and it is now generally referred to as the national concern doctrine.

The first notice of a national concern doctrine as part of the POGG power was by Lord Watson in the Local Prohibitions case:

$+4$

$+7$

$4 x$

49

Ibid. at s. 91.

Ibid.

P. Hogg, Constitutional Law of Canada, 4th ed. (Toronto: Carswell, 1997) at 447-69 (hereinafter Hogg].

Ibid. at $443-44$. 
Their Lordships do not doubt that some matters, in their origin local and provincial, might attain such dimensions as to affect the body politic of the Dominion. and to justify the Canadian Parliament in passing laws for their regulation or abolition in the interest of the Dominion. But great caution must be observed in distinguishing between that which is local or provincial. and therefore within the jurisdiction of the provincial legislatures, and that which has ceased to be merely local or provincial. and has become matter of national concern, in such sense as to bring it within the jurisdiction of the Parliament of Canada. ${ }^{\text {so }}$

For many years after the Local Prohibitions case the Privy Council ignored Lord Watson's national concern dictum by insisting that it could only be justified by a national emergency. ${ }^{51}$ The resurgence of the national concern component of the POGG power was initiated by Viscount Simon:

\begin{abstract}
In their Lordships' opinion, the true test must be found in the real subject matter of the legislation: if it is such that it goes beyond local or provincial concern or interests and must from its inherent nature be the concern of the Dominion as a whole ... then it will fall within the competence of the Dominion Parliament as a matter affecting the peace, order and good government of Canada, though it may in another aspect touch on matters specially reserved to the provincial legislatures. ${ }^{52}$
\end{abstract}

The national concern doctrine of the POGG power has since been recognized in a number of cases. In Johannesson v. West St. Paul, ${ }^{53}$ it was used to uphold aeronautics within the exclusive authority of Parliament because air travel had ceased being merely a local or provincial concern. In Munro v. Canada (National Capital Commission), ${ }^{54}$ it was held that the municipal area around Ottawa was a matter of national concern. Justice Cartwright, speaking for a unanimous Supreme Court of Canada, reasoned that "the development, conservation and improvement of the National Capital Region in accordance with a coherent plan" 55 is a matter which "goes beyond local or provincial interests." $" .6$

For the purpose of this article, the most important application of the national concern doctrine is the 1988 case of $R$. v. Crown Zellerbach. ${ }^{57}$ In that case, the federal Ocean Dumping Control $\mathrm{Act}^{58}$ was upheld in its prohibition on dumping in the provincial marine waters of British Columbia (the Ocean Dumping Control Act was enacted as Parliament's fulfillment of the Convention on the Prevention of Marine Pollution by Dumping of Wastes and other Matter ${ }^{59}$ ). For the majority, Le Dain J. held that:

Ontario (A.G.) v. Dominion of Canada (A.G.), [1890] A.C. 348 at 361 [hereinafter Local Prohibitions case].

Hogg, supra note 48 at 451.

Ontario (A.G.) v. Canada Temperance Federation, [1946] A.C. 193 at 205-206.

[1952] 1 S.C.R. 292.

[1966] S.C.R. 663 [hereinafter Munro].

Ibid. at 671 .

lbid.

[1988] I S.C.R. 401 [hereinafter Crown Zellerbach].

S.C. 1974-75-76, c. 55.

Convention on the Prevention of Marine Pollution by Dumping of Wastes and other Matter, 29

December 1972, 1046 U.N.T.S. 139 [hereinafter Convention]. 
"Marine pollution, because of its predominantly extra-provincial as well as international character and implications, is clearly a matter of concern to Canada as a whole." ${ }^{60}$ The national concem doctrine was also used as part of the basis for deciding that atomic energy falls under federal jurisdiction. ${ }^{61}$ Justice La Forest, for the majority, stated that atomic energy is a matter of national concern because "it is predominantly extraprovincial and international in character and implication" because of potential national security and environmental issues. ${ }^{62}$ These cases have demonstrated that extraprovincial and international implications can justify the federal government's POGG power - the matter has ceased to be just a local or provincial concern. The logical question is, therefore, what is a sufficient national concern that will invoke federal authority?

In Crown Zellerbach, the court reviewed the jurisprudence of the national concern doctrine and developed four conclusions as to its principles:

1. The national concern doctrine is separate and distinct from the national emergency doctrine of the peace, order and good government power, which is chiefly distinguishable by the fact that it provides a constitutional basis for what is necessarily legislation of a temporary nature;

2. The national concern doctrine applies to both new matters which did not exist at Confederation and to matters which, although originally matters of a local or private nature in a province, have since, in the absence of national emergency, become matters of national concern;

3. For a matter to qualify as a matter of national concern in either sense it must have a singleness, distinctiveness and indivisibility that clearly distinguishes it from matters of provincial concern and a scale of impact on provincial jurisdiction that is reconcilable with the fundamental distribution of legislative power under the Constitution;

4. In determining whether a matter has attained the required degree of singleness, distinctiveness and indivisibility that clearly distinguishes it from matters of provincial concem it is relevant to consider what would be the effect on extra-provincial interests of a provincial failure to deal effectively with the control or regulation of the intra-provincial aspects of the matter. ${ }^{63}$

The third and fourth principles are of critical importance for investigating the application of federal POGG power to GHG control. The third principle is essentially that the matter of national concern must have a "singleness, distinctiveness and indivisibility" ${ }^{64}$ in a manner that is reconcilable with the constitutional division of powers. The fourth principle is generally referred to as the provincial inability test: "that provincial failure to deal effectively with the intra-provincial aspects of the matter could have an adverse effect on extra-provincial interests." 65

The Constitution complicates environmental initiatives because "environmental protection" and "pollution" are not enumerated heads of power under either the s. 92

Crown Zellerbach, supra note 57 at 436.

Ontario Hydro v. Ontario (Labour Relations Board), [1993] 3 S.C.R. 327 [hereinafter Ontario Hydro].

Ibid. at 379.

Crown Zellerbach, supra note 57 at $431-32$.

Ibid.

Ibid. at 434. 
provincial or s. 91 federal powers. The Supreme Court of Canada has "unanimously held that the environment is a subject matter of shared jurisdiction, that is, that the Constitution does not assign it exclusively to either the provinces or Parliament." Rather, the environment "encompasses the physical, economic and social environment touching several of the heads of power assigned to the respective levels of government." ${ }^{17}$

The consequence of determining that certain activities are within the national domain, by virtue of the POGG power, is that provincial jurisdiction over these activities is prevented. This result has an "obvious impact on the balance of Canadian federalism." ${ }^{\text {" T }}$ The fact that environmental pollution, in the words of Professor Lederman, is a "sweeping subject ... virtually all-pervasive in its legislative implications" ${ }^{169}$ is an important concern for balanced federalism. Lederman's thesis is that if environmental pollution was to become a new broad category of federal power, it will take over a wide range of existing provincial powers.

The concern that environmental pollution, if held to be exclusively under federal authority, could overwhelm the division of powers has been echoed in the large dissents of Crown Zellerbach and Hydro-Québec. In Crown Zellerbach, marine pollution was held to invoke the federal POGG power by a 5-4 split decision. While the majority believed that the distinction between salt water and fresh water had sufficient singleness, distinctiveness and indivisibility, ${ }^{70}$ the dissent rejected that reasoning. For the dissent, La Forest J. stated that the broad prohibition on any dumping without a permit (before there was even any evidence the dumped substances were deleterious) creates "considerable stress on Canadian federalism." Justice La Forest believed that the allocation of this type of environmental pollution exclusively to Parliament "would ... involve sacrificing the principles of federalism enshrined in the Constitution." 72 In contrast, the majority considered the principle emphasized in Re Anti-Inflation Act: ${ }^{73}$ "that in order for a matter to qualify as one of national concern falling within the federal peace, order and good government power it must have ascertainable and reasonable limits, in so far as its impact on provincial jurisdiction is concerned." ${ }^{14}$ The majority held that the distinction between dumping in fresh water and salt water created the ascertainable and reasonable limits that permitted the intrusion on provincial jurisdiction. The federal legislation was only concerned with ocean dumping and did not apply to other activities that may also affect marine pollution, such as air emissions or dumping into rivers (which would have been a much more intrusive infringement on provincial authority).

[1997] 3 S.C.R. 213 at para. 59 [hereinafter Hydro-Québec].

Friends of the Oldman River Society v. Canada (Minister of Transport), [1992] I S.C.R. 3 at 63. Hydro-Quebec, supra note 66 at para. 115.

W.R. Lederman, "Unity and Diversity in Canadian Federalism: Ideals and Methods of Moderation" (1975) 53 Can. Bar Rev. 597 at 610.

Crown Zellerbach, supra note 57 at 437.

Ibid. at 451.

Ibid. at 455.

[1976] 2 S.C.R. 373.

Crown Zellerbach, supra note 57 at $437-38$. 
The dispute in Hydro-Quebec was whether the Canadian Environmental Protection $A c t^{75}$ provisions for regulating the releases of "toxic substances" into the environment were ultra vires Parliament. The provincial utility had been charged with dumping polychlorinated biphenyls (PCBs), a group of highly toxic and persistent chemicals if released into the environment. ${ }^{76}$ The majority upheld the $C E P A$ in a 5-4 decision, on the basis that it was valid criminal law. As a result, they did not consider whether the provisions could fall under the national concern doctrine. However, the dissent did evaluate whether the CEPA could be justified by national concern and ultimately rejected it under those circumstances. The dissent believed that the definition of "toxic substances" did not satisfy the test for singleness, distinctiveness and indivisibility because it was "an all-encompassing definition with no clear limits." The dissent held the test to be a difficult one:

Because of the high potential risk to the Constitution's division of powers presented by the broad notion of "national concern," it is crucial that one be able to specify precisely what it is over which the law purports to claim jurisdiction. Otherwise "national concern" could rapidly expand to absorb all areas of provincial authority. ${ }^{78}$

The dissent, observing the distinction in Crown Zellerbach between fresh and salt water, could not find an analogous distinction between different toxic substances in the $C E P A{ }^{79}$ If the definition of toxic substances had made a clear distinction on bases such as persistence or toxicity, so as to put ascertainable limits on the federal power, it appears that the dissent may have upheld the provisions based on POGG. ${ }^{80}$

The essence of Principle 3 is that, because invoking the national concern doctrine results in restrictions on provincial powers, these matters must have clear distinctions that establish ascertainable boundaries. Broad federal matters that could overwhelm balanced federalism will likely not be upheld.

Principle 4, the "provincial inability" test, was an important consideration of the majority decision in Crown Zellerbach. This test assists in the determination of singleness, distinctiveness and indivisibility because it is the "inter-relatedness of the intra-provincial or extra-provincial aspects of the matter that ... requires a single or uniform [national] legislative treatment." ${ }^{81}$ The majority held that since marine pollution has extra-provincial and international implications it is a matter of national concern; provincial failure to prevent marine pollution could lead to the pollution of other provincial waters and could cause Canada to be in breach of the Convention. ${ }^{82}$

R.S.C., 1985, c. 16 (4th Supp.) [hereinafter CEPA].

Hydro-Quebec, supra note 66 at para. 158.

lbid. at para. 69.

lbid. at para. 67.

lbid. at para. 75 .

lbid.

Crown Zellerbach, supra note 57 at 434.

Convention, supra note 59. 
However, it is important to recognize that the majority placed much greater significance on Principle 3 than on the provincial inability test. ${ }^{83}$

In Ontario Hydro, the Court applied the provincial inability test to rule that a provincial failure to sufficiently regulate nuclear energy could result in the risk of a human health and environmental catastrophe of extra-provincial and international implications. ${ }^{84}$ The POGG analysis by the dissent in Hydro-Québec also looked at the results of provincial failure to regulate if federal authority was not upheld. The dissent appeared to indicate that they would accept the provincial inability test because the persistent and toxic effects of PCBs would have grave extra-provincial consequences if any one province failed to regulate their emissions. ${ }^{85}$ However, because the definition of toxic substances can potentially capture much more than just PCBs, the dissent rejected this argument.

\section{B. Application to Greenhouse Gas CONTROL}

Can the federal government rely on the national concern doctrine of the POGG power to justify a GHG-emissions trading program? Two environmental lawyers disagree on this issue. Rolfe believes there is a "strong likelihood that the courts would uphold direct federal regulation as a matter of national concern, but the exact limits of this federal power are uncertain." ${ }^{86}$ Castrilli believes that the courts would be greatly reluctant to justify federal legislation on the "national concern doctrine given the potential impact on provincial authority in the same area." ${ }^{87}$ Rather than POGG, Castrilli is of the opinion that, for trading, the trade and commerce power is most appropriate for federal constitutional authority. ${ }^{88}$ This enumerated head of power is analyzed in Part III.

Rolfe has two main arguments for his opinion: that greenhouse gas regulations possess the requisite singleness, distinctiveness and indivisibility; and that the Kyoto Protocol is analogous to the Convention on the Prevention of Marine Pollution by Dumping of Wastes and other Matter ${ }^{89}$ Even though the sources of GHG emissions are numerous, Rolfe believes that, in the case law, they are "treated as a distinct topic within environmental protection distinct from local air pollution, toxic pollution and regional air pollution." 90

There are number of reasons supporting Rolfe's first argument:

(1) climate change is a new environmental issue;

(2) GHG substances possess certainty;

k3. Crown-Zellerbach, supra note 57 at 436 .

*. Ontario Hydro, supra note 61 at 379.

ss Hydro-Québec, supra note 66 at para. 76.

w, Rolfe, supra note 15 at 356.

\$7 Castrilli, supra note $\mathbf{4 0}$ at 12 .

x* Ibid. at 19.

*" Rolfe, supra note 15 at 352.

*1 Ibid. at 357. 
(3) ascertainable and reasonable limits on new federal powers can reconcile the intrusion into previously provincial jurisdiction;

(4) GHGs have the singleness, distinctiveness and indivisibility that require uniform national regulation;

(5) provincial failure to regulate GHGs have extra-provincial and international implications.

However, his second argument is unsubstantiated by Crown Zellerbach. The majority in Crown Zellerbach only recognized the international convention from the perspective of the provincial inability test. The majority was much more concerned with the singleness, distinctiveness and indivisibility aspect; they were cognizant of the principle from the Labour Conventions case that the existence of an international treaty does not affect the constitutionality of domestic legislation.

The international concern over GHG-induced climate change is a new environmental issue separate from other air-pollution issues such as acid rain, smog and mercury emissions. There is little uncertainty with "greenhouse gases." The Kyoto Protocol specifies four natural chemicals and two groups of man-made chemicals: carbon dioxide, methane, nitrous oxide, sulphur hexaflouride and hydrofluorocarbons and perfluorocarbons. ${ }^{91}$ Environment Canada has been monitoring the national emissions of these chemicals since $1990 .^{92}$ As a result, "GHGs" don't suffer from the same uncertainty as the "toxic substances" that nearly caused the CEPA to be held ultra vires Parliament. $^{93}$

As demonstrated in the dissents in Crown Zellerbach and Hydro-Québec, it is important that "ascertainable and reasonable" limits be established that allow reconciliation of new federal powers with the constitutional division of powers. Since the environment is a shared federal-provincial responsibility, GHG control must not overwhelm provincial environmental protection authority. GHG control by emissions trading could be approached by setting a cap by province, by region or by economic sector. ${ }^{94}$ However, a provincial allocation may be unworkable because of a heavy burden on Alberta and Ontario (these two provinces alone represent 31 percent and 28 percent, respectively, of national emissions in $1999^{95}$ ). Also, a provincial cap with federal instructions to do whatever is necessary to reduce emissions is a circular argument that comes back to the provincial inability test. In other words, if the provinces are capable of reducing GHGs then why is POGG being invoked? As a result, a cap declared on each economic sector (such as a certain reduction for the oil and gas industry, another for the pulp and paper industry, another for agriculture, etc. ${ }^{96}$ ) may be more palatable and would, furthermore, recognize that some provinces may resist implementing GHG reductions.

Kyoto Protocol, supra note 2 at Annex A.

A. Jaques, F. Neitzert \& P. Boileau, Trends in Canada's Greenhouse Gas Emissions (1990-1995)

(Ottawa: Environment Canada, 1997); Neitzert el al., supra note 14.

Hydro-Québec, supra note 66.

Bachelder, supra note 40 at 290.

Greenhouse Gas Division, supra note 12.

Bachelder, supra note 40 at 291. 
Emissions trading in a sector-by-sector approach assists in the argument that federal intrusion has ascertainable and reasonable limits. A cap is set, yet direct intrusion into any specific facilities in any given province is prevented. This could go a long way to reconciling POGG with the "property and civil rights" powers of the provinces. The resulting certainty from the allocation of reductions by sector, likely to be a source of intense federal-provincial and/or federal-industry negotiations, would allay concerns that federal powers would overwhelm the provincial power over industries within their jurisdiction. Therefore, a strong argument can be made for a federal trading system on a sector-by-sector approach.

A further argument assisting the national concern doctrine is that GHGs have the singleness, distinctiveness and indivisibility that requires uniform national management. For emissions trading to function, participation must be mandatory amongst competing businesses. Participation is most likely to be consistent under a federal system. If it were regulated provincially, and provinces were not consistent, businesses in one province may be forced to implement expensive measures while competitors in an adjacent province would not be subjected to similar measures. In fact, this situation would create an incentive for businesses to relocate to so-called "pollution havens" 97 that require less strict GHG measures - a wholly unsatisfactory situation. Preventing these competitiveness issues by using a national management process would be important for emissions trading, for ensuring confidence in the carbon commodity, and to prevent some businesses from being penalized for being located in GHG-proactive provinces.

The provincial inability test will play a large role during judicial considerations about whether GHG regulations warrant the national concern doctrine. Once emitted, greenhouse gases can have long lifespans in the atmosphere. ${ }^{98}$ The GHG emissions from any province will, during their lifespan in the atmosphere, contribute to climate change outside that province and outside Canada. In fact, Canada's future liability as a result of contributing to climate change-induced impacts in vulnerable nations has already been the source of legal research. ${ }^{99}$ If Canada consents to the obligations of the Kyoto Protocol, provincial failure to regulate GHG emissions could risk violation of this treaty. A province's inability or resistance to reducing GHG emissions could contribute to climate change extra-provincially and internationally and may cause the

E.A. Fitzgerald, "The Constitutionality of Toxic Substances Regulation under the Canadian Environmental Protection Act" (1996) 30 U.B.C. L. Rev. 55 at 93.

While the atmospheric lifespan of carbon dioxide is variable, the lifespan of methane is estimated at 12 years; the lifespan of nitrous oxide is estimated at 120 years; the lifetime of sulphur hexaflouride is estimated as 3,200 years; the lifetime of hydrofluorocarbons ranges between 50 and 1,700 years; and the lifetime of perfluorocarbons ranges between 2,600 and 50,000 years. See Intergovernmental Panel on Climate Change, "Climate Change 1995: The Science of Climate Change. Contribution of Working Group 1 to the Second Assessment Report of the Intergovernmental Panel on Climate Change," ed. by J.T. Houghton et al. (New York: Cambridge University Press, 1995) at 92-93.

* P.K. Barton, "State Responsibility and Climate Change: Could Canada be Liable to Small Island States?" (2002) 11 Dal J. Leg. Stud. [forthcoming]. 
breach of an important international environmental treaty. These factors will weigh heavy when balancing the justifications of the national concern doctrine.

Arguments opposing the national concern doctrine for GHG regulation would likely begin with s. $92 \mathrm{~A}$ of the Constitution. GHG control is arguably direct legislation that would restrict the development of Alberta's fossil-fuel resources and thus conflict with s. 92A(1). This provision of the Constitution grants provincial governments the exclusive authority over the "exploration ... development, conservation and management of non-renewable natural resources." 100 However, the counter-argument to any province asserting s. $92 \mathrm{~A}(1)$ is that non-renewable natural resources, that is, fossilfuel resources, are no longer simply a provincial matter. Because of climate change, these resources have been elevated to the status of national concerns. The federal government could argue that the intent of provincial powers under the Constitution is only for jurisdiction over local or provincial matters. Evidence of this intent is demonstrated by s. 92(10), where provinces have authority over transportation or communication related to "local works and undertakings" unless they are extraprovincial or international. Further evidence can be found in the residuary clause, $s$. 92(16): "generally all matters of a merely local or private nature in the province."

An additional argument opposing the national concern doctrine would bring attention to the sheer number of potential sources of emissions. Environment Canada divides the inventory of national emissions into seven main groups - electricity and petroleum industries; transportation; industry; residential, commercial and institutional sector; agriculture; land-use change and forestry; and waste. These main groups are then further divided into numerous subcategories. ${ }^{101}$ Provincial governments will likely argue that federal regulation of GHGs would involve regulating every industrial, commercial, institutional and private activity which occurs in each of the provinces. This argument can be rebutted by heeding the previous discussion on ascertainable and reasonable limits. Trading only sets mandatory targets - it does not specify the measures to be taken to reach those targets. By these tenets, federal regulations can be carefully designed with clear boundaries that minimize intrusion into local or provincial matters, such as land-use planning or transportation, while still realizing GHG reductions.

In summary, the POGG power presents a strong possibility for federal legislative authority to implement a GHG-trading system. As long as legislation is carefully designed with balanced federalism and "ascertainable" limits in mind, there is a good possibility that the national concern doctrine of POGG could provide the constitutional basis for instituting mandatory emission targets.

\section{Criminal Law Power}

This part explores a second federal power which could play a role in the federal regulation of GHG emissions - the criminal law power. 


\section{A. BACKGROUND}

The criminal law is exclusively within federal jurisdiction as a result of s. 91(27) of the Constitution. The Margarine Reference of 1949 provides the seminal definition of criminal law:

A crime is an act which the law, with appropriate penal sanctions, forbids; but as prohibitions are not enacted in a vacuum, we can properly look for some evil or injurious or undesirable effect upon the public against which the law is directed. That effect may be in relation to social, economic or political interests; and the legislature has had in mind to suppress the evil or to safeguard the interest threatened.

Is the prohibition enacted with a view to a public purpose which can support it as being in relation to criminal law? Public peace, order. security, health, morality: these are the ordinary though not exclusive ends served by that law. ${ }^{102}$

There are three prerequisites to a valid criminal law: a valid criminal law purpose, a prohibition, and a penalty. ${ }^{103}$ The valid purpose of criminal law is flexible because it has been expanded from "public peace, order, security, health [and] morality"104 to include environmental protection, as noted in Hydro-Québec. Speaking for the majority on the criminal law issue in RJR-MacDonald Inc. v. Canada (A.G.), La Forest J. stated "The criminal law power is plenary in nature and this Court has always defined its scope broadly.... In developing a definition of the criminal law, this Court has been careful not to freeze the definition in time or confine it to a fixed domain of activity." 105 In a similar manner as with other constitutional questions, the courts determine whether legislation is criminal law by looking at its pith and substance and then comparing that with the definition of valid criminal law. ${ }^{106}$

Three recent Supreme Court of Canada decisions examined the definition of criminal law: RJR-MacDonald, Hydro-Québec and the Firearms Reference. These cases are of particular importance, and are reviewed below.

\section{RJR-MACDONALD}

In RJR-MacDonald, a federal act which prohibited all tobacco advertising was upheld by a seven-judge majority as valid criminal law. This was despite the fact that advertising is a provincial matter. While this act was struck down on other grounds, the criminal law component of this decision adds an important contribution to the jurisprudence in this area. The statute was held to be criminal law because tobacco advertising encouraged hazardous tobacco consumption and thus raised serious health concerns. Justice La Forest, for the majority, held that "Parliament [can] validly employ

Reference re Validity of Section 5(a) of the Dairy Industry Act, [1949] S.C.R. 1 at 49-50 [hereinafter Margarine Reference] [emphasis added].

Firearms Reference, supra note 36.

Margarine Reference, supra note 102.

[1995] 3 S.C.R. 199 at para. 28 [hereinafter RJR-MacDonald].

Ibid. at para. 29. 
the criminal law to prohibit tobacco manufacturers from inducing Canadians to consume their products." To understand this case it is important to recognize that "health" is not an enumerated head under the Constitution. In Schneider v. The Queen, ${ }^{107}$ Estey J. observed that "'health" is not a matter which is subject to specific constitutional assignment but instead is an amorphous topic which can be addressed by valid federal or provincial legislation, depending in the circumstances of each case on the nature or scope of the health problem in question." 108 This concept of "health" as a shared federal-provincial responsibility bears striking similarity with the concept of the "environment" as a shared responsibility (discussed in Part I, above). ${ }^{109}$

The tobacco manufacturer in RJR-MacDonald raised three arguments worthy of review:

(1) the act cannot be criminal law if Parliament has chosen to prohibit the advertising of the harmful product, but not the actual consumption of the harmful product;

(2) tobacco consumption and advertising have always been legal and so the "legislation does not serve a "public purpose commonly recognized as being criminal in nature"", 110

(3) since the act has a number of exemptions it is regulatory, not criminal.

Justice La Forest rejected all of these arguments. The first argument, the prohibition on advertising but not actual consumption, was rejected on the following basis:

[T]here is a compelling explanation for this choice. It is not that Parliament was attempting to intrude colourably upon provincial jurisdiction [to regulate advertising] but that a prohibition upon the sale or consumption of tobacco is not a practical policy option at this time.... Given the addictive nature of tobacco products, and the fact that over one-third of Canadians smoke, it is clear that a legislative prohibition on the sale and use of tobacco products would be highly impractical. ${ }^{\prime \prime \prime}$

In La Forest J.'s opinion, the complexities of reducing Canadians' tobacco consumption require "innovative legislative solutions." 112

The argument that tobacco consumption and advertising have always been legal was also rejected: "[it is a] well established principle that the definition of criminal law is not 'frozen as of some particular time' ${ }^{\prime 113]} \ldots$... It has long been recognized that Parliament's power to legislate with respect to the criminal law must, of necessity, include the power to create new crimes."1/4 Even though tobacco consumption and advertising have historically been legal, La Forest J. held that that does not prevent

[1982] 2 S.C.R. 112.

lbid. at 142 .

This similarity will be explored in the next Section: Application to Greenhouse Gas Control. RJR-MacDonald, supra note 105 at para. 46.

Ibid. at para. 34.

Ibid. at para. 36.

La Forest J. cites R. v. Zelensky, [1978] 2 S.C.R. 940 at 95 !.

$R J R-M a c D o n a l d$, supra note 105 at para. 47. 
Parliament from criminalizing either activity today. ${ }^{115}$ His reasoning is supported by the fact that lawful tobacco advertising and consumption preceded the scientific understanding of the hazards of these products. There is now "compelling evidence concerning the health effects of tobacco consumption" 116 which necessitates new legislation.

The exemption argument that the Act must be regulatory, and not criminal, was rejected because of the "long-established principle that the criminal law may validly contain exemptions for certain conduct without losing its status as criminal law."117 As authorities for this principle, La Forest J. cites Lord's Day Alliance of Canada v. British Columbia (A.G.), ${ }^{118}$ Morgentaler v. The Queen ${ }^{119}$ and R. v. Furtney. ${ }^{120}$ In Lord's Day, the criminalization of Sunday gambling was upheld even though there were exemptions for provinces which legislated to the contrary. In Morgentaler, there was an exemption to the criminal prohibition against intentional miscarriages in cases where the woman's life was in danger. Furtney upheld the exemption for provincial regulation of lotteries despite the fact they were prohibited in the Criminal Code. ${ }^{121}$

Justice Major, dissenting on the criminal law issue (with Sopinka J. concurring), believed that the "criminal sanction must pose a significant, grave and serious risk of harm to public health, morality, safety or security" 122 and later held that tobacco advertising does not present "such a significant, grave and serious danger to public health to become criminal law." 23 Given that Health Canada estimates that smoking causes the premature deaths of 30,000 Canadians and 29 percent of the deaths from cancer every year, ${ }^{124}$ and that some of this must be a result of inducement by advertising, it is unclear exactly when Major $\mathrm{J}$. would believe an issue possesses sufficient significance, gravity or seriousness.

\section{HYDRO-QUE'BEC}

In Hydro-Québec, a 5-4 majority of the Supreme Court of Canada criminalized an aspect of environmental protection - the regulation of "toxic substances" as defined by the CEPA. This expanded the traditional purposes of the criminal law - the purposes of public peace, order, security, health, and morality. ${ }^{125}$ For the majority, La Forest $J$. stated that "[t]he purpose of criminal law is to underline and protect our fundamental values," 126 and concluded that environmental stewardship is one of those

Ibid. at para. 48.

Ibid.

lbid. at para. 53.

[1959] S.C.R. 497 [hereinafter Lord's Day].

[1976] 1 S.C.R. 616 [hereinafter Morgentaler].

[1991] 3 S.C.R. 89 [hereinafter Furmey].

R.S.C. 1985, c. C-46, s. 207.

RJR-MacDonald, supra note 105 at para. 200.

Ibid. at para. 209.

Ibid. at para. 31.

Margarine Reference, supra note 102 at 49-50.

Hydro-Québec, supra note 66 at para. 127. 
fundamental values: "The protection of the environment, through prohibitions against toxic substances, seems to me to constitute a wholly legitimate public objective in the exercise of the criminal law power." ${ }^{27}$ The dissent agreed with the majority that an aspect of environmental protection can be the basis of criminal law but rejected the $C E P A$ as valid criminal law. The dissent had five main arguments:

(1) the CEPA regulates "toxic substances," but criminal law must prohibit not regulate; $; 28$

(2) while blanket prohibitions are not necessary - exemptions can exist - there must first be a prohibition; ${ }^{129}$

(3) because it is Ministerial discretion which deems certain chemicals as "toxic substances," the Executive is creating criminal offences; ${ }^{130}$

(4) the equivalency provisions of the CEPA are very unusual for criminal law because provinces cannot enact criminal law; ${ }^{131}$

(5) the broad definition of "toxic substances" will give the federal government total control over the release of all pollutants and thus infringe provincial powers. ${ }^{132}$

The regulation argument was addressed by La Forest $\mathrm{J}$. in his observation that of the 21,000 registered substances in commercial use only 25 have been found "toxic" under the CEPA definition. ${ }^{133} \mathrm{By}$ "having regard to the particular nature and requirements of effective environmental regulation," ${ }^{134}$ he held that the provisions were not regulatory in nature. ${ }^{135}$

Justice La Forest rejected the argument that the definition of toxic substances under $C E P A$ is so broad as to encroach on provincial jurisdiction, on the basis that it fails to consider the overall purpose of the $C E P A .{ }^{136} \mathrm{He}$ accepted the observation of Gonthier J. in Ontario v. Canadian Pacific, ${ }^{137}$ that broad wording is necessary in the context of environmental protection:

What is clear from this brief review of Canadian pollution prohibitions is that our legislators have
preferred to take a broad and general approach, and have avoided an exhaustive codification of every
circumstance in which pollution is prohibited. Such an approach is hardly surprising in the field of
environmental protection, given that the nature of the environment (its complexity, and the wide range
of activities which might cause harm to it) is not conducive to precise codification. Environmental
protection legislation has, as a result, been framed in a manner capable of responding to a wide variety

Ibid.

Ibid. at para. 147.

lbid. at para. 134.

[1995] 2 S.C.R. 1031. 
of environmentally harmful scenarios, including ones which might not have been foreseen by the drafters of the legislation. ${ }^{138}$

Justice La Forest's analysis of the purpose of the CEPA, in light of Gonthier J.'s opinion that broad wording is necessary to respond to unforeseen consequences, concluded that "there was no intention that the Act should bar the use, importation or manufacture of all chemical products, but rather it should affect only those substances that are dangerous to the environment, and then only if they are not regulated by law." 139 While the basis of federal authority on criminal law was only upheld by a slim majority of the Court, this case stands as an important application of the criminal law to the field of environmental protection.

\section{FIREARMS REFERENCE}

In the Firearms Reference, a unanimous Supreme Court of Canada upheld the federal Firearms $\mathrm{Act}^{140}$ - legislation which controlled access to firearms - on the basis of the traditional criminal law purpose of public safety.

One of the main arguments raised by Alberta, the party challenging the legislation, was that the Firearms Act was regulatory, not criminal, in nature. The grounds for this argument, inter alia, were that the Firearms Act was complex ${ }^{141}$ and that criminal gun control could only be a complete prohibition. ${ }^{142}$ The complexity argument was rejected because the Court observed that other complex federal statutes have previously been upheld under the criminal law power. These have included the Food and Drugs $A c t,{ }^{143}$ which was upheld in $R$. v. Wetmore, ${ }^{144}$ and the CEPA which was upheld in Hydro-Québec. The complete-prohibition argument was rejected because of the extensive jurisprudence to the contrary. Reference re ss. 193 and $195 . I(I)(c)$ of the Criminal Code ${ }^{145}$ and RJR-MacDonald established that Parliament may use "indirect means to achieve its end ... [and that] direct and total prohibition is not required."146 Furthermore, the Court relied on the same trilogy of cases as in RJR-MacDonald to demonstrate that exemptions from a law do not prevent it from being criminal: Lord's Day, Morgentaler and Furtney.

Many readers are likely already aware of the similarities which exist between the issues raised in RJR-MacDonald, Hydro-Québec and the Firearms Reference and the potential application of the criminal law to GHG trading: the criminal law can be utilized for environmental purposes; one could argue that Canadians are addicted to fossil fuels just as they are addicted to tobacco; both "health" and the "environment"

Ibid. at para. 43.

Hydro-Québec, supra note 66 at para. 138.

S.C. 1995 , c. 39.

Firearms Reference, supra note 36 at para. 37.

Ibid. at para. 39.

R.S.C. 1985 , c. F-27.

[1983] 2 S.C.R. 284.

[1990] 1 S.C.R. 1123 [hereinafter Prostitution Reference].

Firearms Reference, supra note 36 at para. 39. 
are a shared federal-provincial responsibility; and complex legislation with exemptions does not preclude it from being criminal in nature. The next section explores the possibility of the Parliament using their exclusive jurisdiction over criminal law to reduce Canada's GHG emissions.

\section{B. Application to Greenhouse Gas Control}

Can the federal government rely on the criminal law power to implement a national emissions trading regime? As an example, Parliament could pass legislation which relies on the criminal sanction to prohibit emissions above a certain level (thereby establishing a "cap"), while allowing trading to occur between the organizations subject to the cap. This trading could be within a single economic sector or between different sectors that are each subject to their own respective criminally sanctioned caps.

Castrilli believes that it would be difficult for the federal government to justify a GHG trading system:

Given the elaborate administrative characteristics of an effective emissions trading regime and the likely need to trade emissions of "non-toxic substances," it would be very difficult to justify such a program under the traditionally narrow ambit of the criminal law power; that is, a prohibition and penalty type regime. ${ }^{147}$

Rolfe is not as pessimistic as Castrilli, though he states "using the criminal law power to support a complex system of regulation through systems such as emission trading would involve an unprecedented extension of what is considered criminal law." 148 While not specifically examining emissions trading, Dean Hogg is of the opinion, after reviewing Hydro-Québec, that "the federal Parliament probably does have the legal power to enact ... legislation that would force emissions targets down to the Kyoto target." 149

Recognizing the three prerequisites to criminal law (a criminal purpose, a prohibition and a penalty), unco-operative provincial governments would likely challenge such legislation using the following arguments:

(1) that Parliament must completely prohibit GHG emissions for such prohibitions to be criminal law - merely settings caps is regulatory;

(2) that GHG emissions have always been lawful, so Parliament can't criminalize them now;

(3) that an emissions trading system will be complex and so must be regulatory;

(4) that emissions trading systems will probably need exemptions and ministerial discretion to accommodate the difficulties of certain sectors; and 
(5) that the "environment" is a shared federal-provincial responsibility, so the federal government cannot make an aspect of environmental protection its exclusive jurisdiction.

Similar arguments to these were addressed and ultimately rejected in $R J R-M a c D o n a l d$, Hydro-Québec and the Firearms Reference. The fact that GHG emissions have been completely unrestricted in the past will not preclude Parliament from creating new criminal law. Remember that criminal law is not "frozen as of some particular time." 150 Furthermore, a strong analogy can be made between the new criminal sanction on tobacco advertising and new criminal sanctions on GHG emissions. In RJRMacDonald, La Forest J. observed that unrestricted tobacco advertising and consumption preceded the scientific understanding of the hazards of tobacco. Now that considerable evidence of the hazards of tobacco exists, Parliament can respond with new legislation. In a similar manner, the previous absence of any restrictions on GHG emissions, which began long before the greenhouse effect was understood, cannot now be a defence to the policy response to the risks of climate change. The federal government would argue that the available scientific understanding of climate change, while not completely definitive, justifies new criminal legislation. ${ }^{151}$

The important legal principle from Hydro-Québec was that environmental protection could be included along with the traditional criminal law purposes of maintaining public peace, order, security, health and morality. Obviously, this raises the possibility that the GHG aspect of environmental protection could also be valid criminal law in a similar manner to the "toxic substances" aspect.

The argument that, in order for Parliament to enact criminal law there must be a complete prohibition, can also be rejected based on the jurisprudence on this issue. Indirect prohibitions occurred in both the Prostitution Reference and RJR-MacDonald. The effectiveness of challenged legislation is not at issue - only the constitutionality is. In $R J R-M a c D o n a l d$, the prohibition on tobacco advertising, a provincial matter, was accepted because of the practical reality of tobacco products in Canada. A majority of the Court believed that a complete prohibition would not have been possible because of their addictive nature, and because over one-third of Canadians smoke. This practical reality necessitated "innovative legislative solutions." 152 Indirect criminal sanction by a GHG cap, instead of a complete prohibition on GHG emissions or GHG production, is an innovative policy in light of the fact that Canadians are arguably addicted to fossil fuels. As stated in the Introduction, above, fossil fuels accounted for $\mathbf{7 8}$ percent of

1s4. See supra note 114.

[s] For the current scientific understanding of climate change and its impacts, refer to Intergovernmental Panel on Climate Change, Climate Change 2001: The Scientific Basis: Contribution of Working Group I to the Third Assessment Report of the Intergovernmental Panel on Climate Change, ed. by J.T. Houghton et al. (New York: Cambridge University Press. 2001); Intergovernmental Panel on Climate Change, Climate Change 2001: Impacts, Adaptation. and Vulnerability. Contribution of Working Group II to the Third Assessment Report of the Intergovernmental Panel on Climate Change, ed. by J.J. McCarthy et al. (New York: Cambridge University Press, 2001).

15. R.R-MacDonald, supra note 105 at para. 34 
national emissions in $1996 .{ }^{153}$ While there are dramatic regional differences, largely because of hydroelectricity and nuclear energy, most Canadians depend on fossil fuelderived energy to satisfy their transportation needs, heat their homes, power their lights and to manufacture the consumer goods required in our post-industrial society. The practical reality is that there cannot be a complete prohibition on GHG emissions. However, indirect regulation of GHGs can reduce this dependency. Just as Parliament criminalized tobacco advertising in an attempt to reduce the tobacco dependency, Parliament could institute a trading regime to reduce fossil fuel consumption.

A supplement to the "complete prohibition" argument is the potential difficulty in partitioning GHG emissions between those that are criminal and those that are lawful. As previously discussed, an emissions trading regime would set mandatory emission targets and there would be a criminal prohibition against emissions in excess of allowable levels. Lawful emissions would include those within the permitted levels and those as a result of natural processes. It is important to recognize that the available scientific understanding of climate change, also discussed above, necessitates the partitioning between criminal, allowable, and natural emissions. This partitioning between the lawful emissions and the prohibited emissions is essentially a restatement of the effectiveness principle from the Prostitution Reference and RJR-MacDonald. Law does not have to be effective, and since it has already been demonstrated that indirect prohibitions are constitutional, there should not be difficulty in this regard.

Even if legislation for an emissions trading system is complex and requires exemptions and ministerial discretion, it can still be valid criminal law. As previously discussed, both the Food and Drugs Act and the CEPA are complex, yet both were upheld as criminal law. Ministerial discretion existed in the $C E P A$ for deeming substances as "toxic," and the Chief Firearms Officer defined in the Firearms Act has discretion to refuse to licence a firearm. ${ }^{154}$ Also previously addressed was the recognition of the existence of exemptions in criminal law. ${ }^{\text {1ss }}$

Provincial governments challenging federal legislation may also argue that because the environment is a shared federal-provincial responsibility, using the criminal law power would create an exclusive federal component, thereby infringing on the shared nature. This argument neglects the fact that while "health" is a shared federal-provincial responsibility, health was the basis for banning tobacco advertising. In fact, the federal government relied upon the health purpose of criminal law in order to acquire legislative authority in this area. Hydro-Québec stands as a further example of Parliament successfully carving an exclusive federal component out of another shared responsibility - that of the "toxic substances" portion of environmental protection.

In summary, the criminal law power could be relied upon as the constitutional basis for a GHG-trading program. While this basis is uncertain because of the many similar

155 Lord's Day, supra note 118; Morgentaler, supra note 119; Furtney. supra note 120. 
characteristics it would have with a regulatory system, the argument may still be made and is supported by the jurisprudence in this area.

\section{Trade ANd Commerce Power}

This part of the present analysis looks at the federal trade and commerce power the last power examined from the perspective of federal jurisdiction for emissions trading.

Section 91(2) of the Constitution confers on Parliament the power to make laws in relation to "the Regulation of Trade and Commerce."156 However, in light of $\mathbf{s}$. 92(13), the provincial authority over "Property and Civil Rights," 157 the federal power over trade and commerce has been narrowly interpreted. In the leading case of Citizens Insurance v. Parsons, ${ }^{158}$ the federal power was restricted to the following two areas:

(1) interprovincial and international trade and commerce; and

(2) "general" trade and commerce affecting the whole country.

As a result of Parsons, it has generally been accepted that intraprovincial trade and commerce is still a matter within provincial power under s. 92(13).

Rolfe observes that the federal trade and commerce power has never been upheld in the context of environmental protection, and he is not optimistic as to its application for emissions trading. ${ }^{159}$ In fact, the four-justice dissent in Hydro-Québec actually considered and rejected an argument by an intervenor that the CEPA could be justified based on trade and commerce. They rejected the argument on the basis that "it is clear that the 'pith and substance' of the impugned legislation does not concern trade and commerce." 160 Rather, the pith and substance was one of environmental protection.

In contrast, Castrilli believes that the trade and commerce power is "the most appropriate constitutional authority for federal emissions trading law."161 He believes that both components of the federal trade and commerce power could be relied upon for legislative authority. The relevant jurisprudence for the two areas of the federal trade and commerce power, and Castrilli's reasoning, is examined below.

\section{A. INTERPROVINCIAL AND INTERNATIONAL TRADE AND COMMERCE}

Examples of the courts' interpretation of the interprovincial and international area of the trade and commere power include $R$. v. Klassen ${ }^{162}$ and Caloil v. Canada

15. Constitution, supra note 29 , s. $91(2)$

Ibid., s. 92(13).

(1881), 7 App. Cas. 96 [hereinafter Parsons].

Rolfe, supra note 15 at 366.

Hydro-Québec, supra note 66 at para. 82 .

Castrilli, supra note 40 at 19.

(1959), 20 D.L.R. (2d) 406 (Man. C.A.), leave to appeal to S.C.C. refused, [1959] S.C.R. ix. 
(A.G.). ${ }^{163}$ In R. v. Klassen, the Manitoba Court of Appeal held that the Canadian Wheat Board $A c t^{164}$ was enacted pursuant to a valid federal authority to regulate the interprovincial and international trade in grain. The regulations the Wheat Board Act imposed on intraprovincial transactions was held to be incidental to its purpose. This operation of the federal trade and commerce power was later affirmed by the Supreme Court of Canada in Caloil. In that case, Parliament had prohibited the transportation or sale of imported oil west of the Ottawa Valley. The law was upheld as "an integral part of the control of imports in the furtherance of an extraprovincial trade policy."165

A further example of the Supreme Court of Canada's reliance on the trade and commerce power is found in Reference re Agricultural Products Marketing Act, 1970 (Canada). ${ }^{166}$ In that case, the federal power was used to uphold a federal eggmarketing scheme as valid legislation. This scheme included federal and related provincial egg-marketing statutes that established quotas for international, interprovincial and intraprovincial trade.

Castrilli believes that a strong analogy can be made between the scheme analyzed in this case and a federal emissions trading program:

The statutory regimes upheld in Re Agricultural Products Marketing Act contain parallels to potential federal and provincial emissions trading regimes, particularly with respect to the setting of national quotas of production for a particular commodity for each province. This could be analogized to a national cap and trading regime for particular pollutant emissions. ${ }^{167}$

However, Hogg is of the opinion that "the case is an unusual one, and may not be an important precedent." 168 His opinion is based on the following observations:

The Court was impressed by the fact that the federal Act was the centrepiece of a cooperative scheme designed to rationalize the national market in eggs. The scheme had been agreed to by all eleven governments, and had been executed by complementary legislation.... A related factor was the extreme difficulty of disentangling the federal and provincial elements of the actual marketing plan for eggs that had been established, under the aegis of the statutes, by a complex undergrowth of regulations and orders emanating from the two levels of government. ${ }^{169}$

When the provincial opposition to GHG regulation is again recognized, it becomes apparent that a similarly cooperative, "entangled," federal-provincial situation for emissions trading is unlikely to present itself.

163 [1971] S.C.R. 543 [hereinafter Caloil].

16 R.S.C. 1952, c. 44 [hereinafter Wheat Board Act].

las Caloil, supra note 163 at 551.

16. [1978] 2 S.C.R. 1198.

167 Castrilli, supra note 40 at 15.

168 Hogg, supra note 48 at 535-36.

$169 \quad$ lbid. at 536. 


\section{B. 'General' TRADE AND COMMERCE}

The Privy Council and the Supreme Court have had a long history of rejecting the "general" trade and commerce power. For example, in Labatt Brewing v. Canada (A.G.), ${ }^{170}$ the Supreme Court of Canada rejected the Food and Drug Cct $^{171}$ on the basis of general trade and commerce, because the FDA was a detailed regulation of a particular industry - even if it was on a national basis. Rather, the general trade and commerce power validated legislation that "affect[s] industry and commerce at large or in a sweeping, general sense."172

The case which resurrected the general trade and commerce power was General Motors of Canada v. City National Leasing ${ }^{173}$ where a unanimous court held that the Combines Investigation Act ${ }^{174}$ was a valid exercise of this largely unutilized federal power: "the Act is quite clearly concerned with the regulation of trade in general, rather than with the regulation of a particular industry or commodity." 175 The conduct that the Combines Act regulated was anti-competitive activity, and the Court believed that this could only be effectively regulated if done nationally. By building on previous jurisprudence, the Court applied a five-part test to determine when federal legislation is of a general trade and commerce nature:

(1) the impugned legislation must be part of a general regulatory scheme;

(2) the scheme must be monitored by the continuing oversight of a regulatory agency;

(3) the legislation must be concerned with trade as a whole rather than with a particular industry;

(4) the legislation should be of a nature that the provinces jointly or severally would be constitutionally incapable of enacting; and

(5) the failure to include one or more provinces or localities in a legislative scheme would jeopardize the successful operation of the scheme in other parts of the country. ${ }^{176}$

The $F D A$ satisfied all five of these elements: there was a regulatory scheme operating under the continuing oversight of a regulatory agency; it was concerned with trade in general; and it was necessary to regulate nationally because of the ability of business to move freely between provinces. ${ }^{177}$

Similar to competition legislation, Castrilli believes that federal emissions trading legislation could also rely on the "general" trade and commerce power for jurisdiction.

170 [1980] 1 S.C.R. 914 [hereinafter Labatt Brewing].

171 R.S.C. 1970 c. F-27 [hereinafter $F D A$ ].

172 Labalt Brewing, supra note 170 at 943.

173 General Motors of Canada v. City National Leasing, [1981] I S.C.R. 641 [hereinafter General Motors].

174 R.S.C., 1970, c. C-23 [hereinafter Combines Act].

i7s General Motors, supra note 173 at 678.

176 Ibid. at 643 .

in Ibid. at $675-82$ 
To the necessary pith-and-substance analysis, Castrilli makes two strong arguments why the dissent in Hydro-Québec was incorrect:

First, pollution does have an important economic dimension in its impact on trade and commerce. There is little incentive for company $A$ to clean up in one province if company $B$ in another province can continue to pollute and thereby obtain an economic advantage over company A.... Second .... [e]missions trading adopts an economic or market approach to environmental pollution by turning, for example, a pollution/emission reduction credit/llowance into an article of trade; that is, a commodity that has economic value to industry. ${ }^{178}$

The first assertion can also be restated as the "pollution haven"179 argument first discussed in Part II, above: if province A forces its industries to implement costly pollution measures, some of these industries may elect to move to province $B$ where similar measures do not exist. Thus environmental pollution is at the mercy of the fluid nature of trade and commerce (thereby necessitating a national regime).

To complete the general trade and commerce argument, Castrilli believes that federal trading legislation could also meet each of the five criteria from General Motors:

First, it would require a general regulatory scheme to implement what would appear to be elaborate components characteristically necessary for emission trades. Second, the regulatory scheme would require continuing oversight and monitoring by the regulatory agency. Third, emissions trading legislation would be concerned with trading in general, albeit trading of emission reduction credits or allowances for certain pollutants, rather than in respect of a particular industry. Fourth, the legislation would be of such a nature that the provinces jointly or severally would be constitutionally incapable of enacting such legislation. Fifth, the failure to include one or more provinces or localities in an emissions trading regime would jeopardize the successful operation of emissions trading in other parts of the country. ${ }^{180}$

However, there are a number of weaknesses in these arguments. While GHG-emission trading can have implications in the area of trade and commerce, that does not change the fact that the dominant purpose of trading is one of environmental protection. Reducing GHG emissions is a response to the concern of global climate change - thus GHG control is an environmental protection initiative. As reviewed in Part 2 above, the environment is a shared federal-provincial responsibility; if the dominant purpose of trading is one of environmental protection, the result is all the inherent constitutional difficulties associated with that subject matter.

The second assertion - that trading is a market-based approach - also faces a similar dominant-purpose argument. In spite of the fact that policy-makers have elected to use an economic instrument to control GHG emissions, the dominant purpose is still one of environmental protection. The commercial relationship with trading is only incidental to the main purpose of environmental protection. 
The final weakness with the "pollution haven" argument is evident when one recognizes that Canadian industry only accounts for about one-third of national emissions (the bulk of the remaining emissions are from transportation, residential and commercial buildings and agriculture). ${ }^{181}$ If trading was justified under trade and commerce (because of the possibilities of pollution havens), then trading could only be justified for the industrial sector. This is because transportation and buildings are not subject to the same competitiveness pressures as industry. As a result, trading would not be applicable to municipal operations, government buildings, agriculture, and so on. In conclusion, even though it is possible for trading to satisfy the five-part test from General Motors, it would probably be rejected by the prerequisite pith-and-substance analysis.

\section{TAXATION}

Assuming provincial opposition, if Parliament is of the opinion that the constitutional authority for emissions trading is vulnerable to challenge, this complicated policy measure may not be pursued. In this situation, the alternative economic instrument of taxing emissions would conceivably gain significance as a possible strategy for reducing national GHGs. This final section of this article examines the federal taxing power.

Section 91(3) of the Constitution confers on Parliament the power to make laws in relation to "the raising of Money by any Mode or System of Taxation." 182 This taxing power is "expressed in the broadest of terms." 183 Both Rolfe and Hogg agree that this provides the federal government with the authority to impose a carbon tax or energy tax on gasoline or other fossil fuels. ${ }^{184}$ The taxation of non-energy GHG emissions is also possible. The only limitation which Hogg perceives on this federal power is that which Alberta successfully argued in Reference re Proposed Federal Tax on Exported Natural Gas, "that federal taxes could not apply to natural gas that the province had extracted from its own Crown lands. This limitation does not help private producers." 185 The proposal for a $10 \notin /$ litre gasoline tax, mentioned in the Introduction, above, is to be discussed at the upcoming Energy and Environment Ministers conference for its two benefits: "it would give the public an incentive to use smaller cars and more efficient engines and provide revenue for Ottawa to fund alternative fuel technologies such as the hydrogen-cell battery." ${ }^{86}$ In summary, Parliament's ability

Based on Canada's 1997 inventory, the emissions from "Industrial Processes," "Fossil Fuel Industries," "Mining," "Manufacturing," and "Construction" total $161 \mathrm{MtCO}_{2} \mathrm{e}$ (see supra note 11). To this total must be added a portion of the emissions from "Electricity and Steam Generation," "Pipelines" and "Fugitive Oil and Gas" - assuming one-half should be allocated to Industry, a final total of $248 \mathrm{MiCO}_{2} \mathrm{e}$ results. Given that Canada's total GHG emissions in 1997 were 682 $\mathrm{MtCO}_{2}$ e, the proportion from Industry is only 36 percent. See Neitzert et al., supra note 14 at 84 .

Ix: Constitution, supra note 29.

1.: G.V. La Forest, The Allocation of Taxing Power under the Canadian Constitution, $2 \mathrm{~d}$ ed. (Toronto: Canadian Tax Foundation, 1981).

184 Rolfe, supra note 15 at 366; Hogg, supra note 48 at 8.

18s [1982] 1 S.C.R. 1004, cited in Hogg, ibid. at 8.

ix. Toulin \& Taber, supra note 22. 
to implement a carbon or energy tax to tax GHG emissions is not subject to the same uncertainty as the authority for establishing a trading regime. As a result, taxation may grow in importance as an alternative economic instrument.

\section{Conclusion}

Nearly five years after Canada signed the Kyoto Protocol, our federal government is still struggling with treaty ratification and domestic implementation. During this time a significant research effort has investigated $\mathrm{GHG}$ emissions trading as a policy measure for realizing cost-effective reductions. However, the recent provincial opposition to the binding emissions targets of the treaty may obstruct the adoption of a trading regime. Without the benefit of provincial co-operation, Parliament would have to rely solely on the federal powers of the Constitution to implement emissions trading. This article has explored three powers which could provide federal jurisdiction: the POGG power, the criminal law power, and, the trade and commerce power. As a result of the lack of clear legislative authority for trading, and public statements by Alberta's provincial government that they will challenge federal GHG initiatives, this article has also analyzed the federal jurisdiction for taxation. Taxing emissions is an alternative economic instrument that is not subject to the same constitutional uncertainty as trading.

The two federal enumerated powers investigated in this article, the criminal law power and the trade and commerce power, are possibilities for providing jurisdiction for trading. However, both present a number of difficulties which may not be overcome in the context of a constitutional challenge. The characteristics a trading program would have in common with a regulatory system may cause a rejection of the assertion that trading is valid criminal law. Reliance on the trade and commerce power for federal jurisdiction over trading will likely fail because trading is in pith and substance environmental protection. Despite the "pollution haven" argument, the dominant purpose of emissions trading is environmental protection and the environment is a shared federal-provincial responsibility.

The residuary federal POGG power increases in importance because of the difficulties with the enumerated powers. As long as legislation is carefully designed with balanced federalism and ascertainable limits in mind, there is a good possibility that the national concern doctrine of the POGG power could provide the constitutional basis for implementing trading. It will be important from the perspective of the constitutionality of trading legislation that trading only sets the emissions cap. Trading does not dictate the specific measures to be undertaken.

The federal taxing power could provide an alternative to emissions trading. Through this power Parliament could establish a carbon or energy tax. The possibility of taxing non-energy GHG emissions also expands the taxation's applicability away from simply the energy or carbon context. Taxation is a broad federal power and does not suffer from the same jurisdictional uncertainty as trading. While there is clear legislative authority for taxation, trading does have the advantage of focusing private or publicsector effort on the lowest-cost reduction initiatives. If emissions taxation is used as an alternative, this advantage will be lost. 
The landscape upon which emissions trading is predicated has been significantly altered by the lack of provincial cooperation in GHG control. The resolution of this constitutional dispute will likely be a source of considerable scholarly interest in the years to come. 